\title{
The Landscape after Brexit as Seen from Ankara. Will the UK's Divorce from the European Union Additionally Loosen Tights Between Europe and Turkey and Have an Impact on the Future of the Continent?
}

\begin{abstract}
On 29 March 2017, President of the European Council Donald Tusk received a note from UK Ambassador Tim Barrow. Under the document, the procedure of UK's leaving of the European Union was initiated. ${ }^{1}$ Gideon Rachman from "Financial Times" compared Brexit to a divorce, stating that the representative of the British government "granted the divorce papers", thus beginning a "long (planned for two years) attempt to redefine mutual relations" (Rozpoczyna się Brexit..., 2017). In his announcement for the press, Donald Tusk commented: "There is no reason to pretend that this is a lucky day, both in Brussels and in London [...] Most Europeans, including almost a half of British voters, would prefer us to be still together" (Wielka Brytania rozpoczyna..., 2017). The stance of the European Council clearly mirrors the moods caused by the decision on Brexit, which are prevailing among all EU member states. It should be noted, however, that leaving the EU by the Brits not only has an impact on their political situation, but it also determines the actions of states aspiring to become members of the Community. The aim of this paper is to discuss the reasons for Brexit and to present the position of the Turkish government on this issue on the basis of the analysis of press articles and politicians' speeches. The hypothesis we posed assumes that Brexit meant Turkey losing its most important advocate in the Union. Thus, the future of accession negotiations between Turkey and the European Union has been called into question. One should also wonder to what degree Turkey's foreign policy priorities, which have already been redefined under the influence of the war in Syria, the battle with ISIS, the immigration crisis and the futile accession process so far, will be affected by the United Kingdom's decision to leave the European Union. Will Turkey choose to follow the so-called Trexit route, giving up its membership in the EU?
\end{abstract}

Key words: Brexit, United Kingdom, Turkey, European Union

$\mathbf{T}$ he issue addressed in the paper is important inasmuch as Brexit significantly reduces the military strength of the Union. There are opinions that the British absence will entail the necessity of finding an alternative - replacement. Some European politicians, including Polish MEP Bolesław Piecha from the Law and Justice party, remind that the European Union signed an agreement with Turkey concerning the immigration crisis caused by the civil war in Syria (Brexit szansq..., 2016). The content of this accord,

1 The United Kingdom European Union membership referendum was held on 25 June 2015. The registered turnout was $72.2 \%$ (46,500,001 of people eligible to vote), and the majority of those voting, i.e. $17,410,742(51.9 \%)$ expressed their approval of the idea of leaving the EU (with 16,141,241, i.e. $48.1 \%$ of those voting against) (see: The Electoral Commission..., 2017). The supporters of Brexit were particularly convinced by the argument that British people are a "free and sovereign nation. We don't join our partners, because we constructively seek ways of developing and balancing our business through trade and cooperation with other sovereign states"(Białek, 2017). 
which was supposed to limit the inflow of refugees from war-stricken areas to Europe, provides the foundations for the law which would allow sending back to Turkey each immigrant who illegally entered the territory of Greece. As compensation, Turkey will receive financial aid, the opportunity to implement solutions which would ensure that its citizens can freely travel in Europe without visas. Turkey was also promised that accession talks would be accelerated (see European Council of..., 2016).

As it was indicated earlier, Brexit made EU politicians remember how strategically important state for Europe Turkey is, especially in the face of current threats to security. Thus, one should agree with the hypothesis of Daniel Kawczyński, member of the British House of Commons from Shrewsbury and Atcham district. He pointed out that Greece should be treated as a "zone of relative stability, which is our only hope for overcoming violence coming from the Middle East" (Białek, 2017).

Great Britain strongly supported Turkey, a country with 80 million citizens, in its efforts to join the European Union. In January 2017, Theresa May said that "Turkey is one of the UK's oldest friends - our relations stretch back over 400 years - but there is much that we can do in the future to build on that relationship together. I'm proud that the UK stood with you on 15 July last year [2016, authors' note] in defence of democracy, and now it is important that Turkey sustains that democracy by maintaining the rule of law and upholding its international human rights obligations as the government has undertaken to do" (Theresa May signs..., 2017). As a result of Brexit, Turks were deprived of their biggest ally in Europe. Analysing comments coming from Turkey, it must be said they are quite moderate. President Recep Tayyip Erdoğan stated that the UK's decision to leave the Community was a surprise for him. In his opinion, it is the European political elites and their policy which should be blamed for this situation. According to Erdogan, if "the EU does not fight its contradictions, there will be more departures" (Brexit szansq..., 2016).

Turkey is a member of all the most important international organisations (Jurkowska, 2010; Ambroziak, 1996, p. 1). The association agreement between the European Economic Community and Turkey was signed on 12 September 1963 (it entered into force on 1 December 1964). Art. 28 of this act stipulated that Turkey may become a fullfledged member of the EEC in future (Jurkowska, 2010). The Turkish government, tired with a lengthy, futile and bureaucratic negotiation process, is becoming less and less interested in joining the European Union. Such feelings are not also reflected in public opinion polls, but they are increasingly often accentuated by politicians, who are nervously responding to the inefficiency of accession talks that began in 2005. What should be emphasised, this lack of progress results from, among other things, from disputes concerning sphere of human rights or the issue of Cyprus. In his recent public statements, the president of Turkey has often indicated that the European Union uses double standards. Referring to the British "divorce" referendum, he noted that "the EU's approach to Turkey is marked by islamophobia. That is why all possible efforts are made to delay our accession to the EU" (Brexit: czy w Europie..., 2016).

Turkey has been a candidate for European Union membership for over 60 years (see Kaleağas1, 2010). Political uno.est in the Middle East and instability on the South-East border of the country (Syria and Iraq), as well as the problem of the inflow of refugees to Turkey (Burak, 2016, pp. 52-78) and Europe, have led to a change in the foreign policy 
of Turkey and made it cement its relations ties with the East, especially Russia (CWA: EС отвечает..., 2010). The Turkish government believes that the strengthening of ties with Russia is detrimental to Europe and will result in the establishment of the new order and leadership in the Middle East. It is indicated that the improvement of relations with Moscow not only goes in line with the interests of Turkey, but it will also bring benefits to Turkish peoples inhabiting the regions of the Caucasus, Central Asia and East Turkestan (see Mikail and others, 2015).

On 23 June 2016, British people voted to leave the EU. This decision shook the global markets, particularly affecting the value of pound sterling (Brytyjczycy wybrali..., 2016).

Turkish Prime Minister Binali Yildirim instantly reacted to the result of the referendum, criticising his British equivalent David Cameron for playing the key part in Brexit. Binali Yildirim pointed out that it was an important signal for the EU to change its policy. Turkey is for a strong European Union - he added (Köylü, 2016). Deputy Prime Minister of Turkey Mehmet Şimşek noted, that by voting to leave the EU, British people opened Pandora's Box. The other deputy, Nurettin Canikli, used stronger words, tweeting that the referendum means the beginning of the process of the disintegration of the European Union. "Great Britain was the first to leave the ship" (Mehmet Şimşek ve..., 2016). Turkish Foreign Affair Minister Mevluta Cavusoglu said that the British referendum surprised everyone, including Turkey, which wants to be a member of this alliance (Mevlüt Çavuşoğlu'ndan Brexit..., 2016).

On the day before the referendum in the United Kingdom, the President of Turkey Recep Tayyip Erdogan said that the EU is a project of Christian expansion and that it is a community the aim of which is to defend Christian ideals and continue its reign over the world. "Europe does not want us because the majority of our population are Muslims." Erdogan proposed that citizens should vote on the issue of Turkey's membership in the EU. One of the options is so called Turexit. "Just like Britons, we can ask the society about our future" - R. T. Erdogan concluded (Altun, 2016).

When commenting on the Brexit campaign in the UK, the Turkish Minister for EU Affairs Ömer Çelik indicated that it was full of Islamophobic motifs and anti-Turkish slogans, which were aimed to inspire anti-immigrant feelings. It should be mentioned that the "Leaving" campaign played on voters' fears connected with immigration, warning them against terrible consequences of the inflow of Muslims, including 79 million of Turks, who would come to the EU (Kasapoğlu, 2016). It is obvious that the United Kingdom was one of the main protagonists of Turkey's membership in the European Union from the start, but in the course of the Brexit debate the immigration from Turkey was used as a threat. Ankara was particularly angered by former Prime Minister David Cameron's meaningful words concerning the risks that Turkey's accession to the European Union entails. Referring to the possible date of Turkey's joining the EU, he said that it would "probably [happen - authors' note] around the year 3000" (Cameron: Türkiye AB'ye..., 2016).

The Turkish opposition also criticised the UK's referendum campaign. According to Öztürk Yılmaz from the Republican People's Party (tur. Cumhuriyet Halk Partisi, CHP), the supporters of the idea of leaving the EU used Turkophobic slogans (CHP'den Brexit..., 2016). Mehmet Günal, the opposition politician from the National Action Party 
(tur. Milliyetçi Hareket Partisi, MHP) pointed out that the result of the referendum in the United Kingdom revealed the British nation's real attitude towards the European Union. He said that Turkey should make the same decision and break off the 50-year engagement as there is still no wedding (Şimşek, 2016).

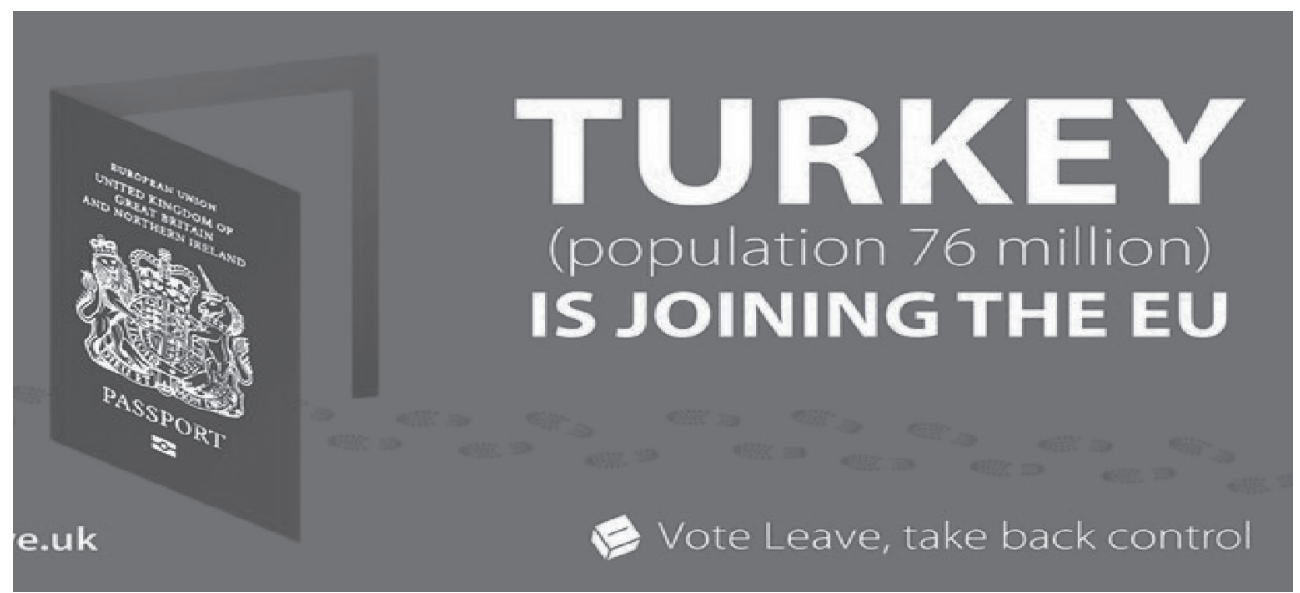

Photo 1. A poster used before the Brexit referendum: "Turkey (population 76 million) is joining the EU. Vote leave, take back control" (Vote Leave embroiled..., 2016)

As can be seen, the UK's leaving the Community opens a new chapter in Turkeys' mutual relations with the European Union. The British referendum campaign was full of negative opinions referring to Turkey, which was noticed by Turkish media. Nevertheless, it should be remembered that it was the United Kingdom that was the sole supporter of Turkey in its efforts to gain the status of EU member, being in opposition to countries that rejected the idea, especially France and Germany (Örmeci, 2016, p. 603). After Britain decided to leave the Community, Turks have lost their main ally and a number of Turkish politicians see no point in waiting further for EU membership. The implications of Brexit make this alliance lose in importance. The public opinion surveys conducted by Turkish polling agencies in recent years show that less than a half of the society have supported Turkey's membership in the EU (see Alkan, 2013, pp. 1-28). Galip Dalay said that the UK's leaving the EU represents one of the most difficult tests in the integration process. Some Turkish politicians believe that, paradoxically, the decision to leave the EU may bring benefits to Ankara, which may skilfully take advantage of Brexit (Dalay, 2016).

The Turkish government declares that Turkey will build new bilateral relations with the United Kingdom in the atmosphere of friendship. Economic ties will play a key part as the cooperation with Britain is important for Turkey mainly because of business reasons (in 2016, the UK market accounted for $8.2 \%$ of Turkish export) (Jarosiewicz, 2017). There are 2,760 British companies in Turkey, including British Airways, HSBC, Tesco, BP, Shell, Vodafone, Marks and Spencer, Harvey Nichols and Commercial Union (Örmeci, 2016, p. 597). What is important, each year almost 2 million Brits spend holidays in Turkey and 100,000 Turks go to Britain on business or for holidays (Örmeci, 2016, p. 598). 
The Turkish Minister of Economy Nihat Zekbekci asserts that Turkey is ready to implement comprehensive trade agreements with the United Kingdom as soon as it leaves the European Union. The government representatives emphasise that bilateral involvement is conducive to an increase in the number of common investment projects and strengthens Turkish-British relations (Турция готова реализовать..., 2016).

On 25-27 September 2016, former Mayor of London and the new Minister of Foreign Affairs of the United Kingdom Boris Johnson paid an official visit to Turkey. He met, among others, Minister of Foreign Affairs Mevlüt Çavuşoğlu, Minister for EU Affairs Ömer Çelik, Prime Minister Binali Yıldırım and President Recep Tayyip Erdoğan (Birleşik Krallık Dışişleri..., 2016). Johnson assured that the United Kingdom would continue to support Turkey's efforts to become a member of the Union structures. The main subjects of the meeting included the issue of Syria, the war against terrorism and the Islamic state, and the immigration problem. Johnson stressed that Turkey has to be a good partner for Britain, which is one of the biggest markets for Turkish products. He joked that he himself had a "beautiful and very reliable Turkish washing machine at home" (Boris Johnson zrobit..., 2016).

It should be noted, however, that some unfortunate comments have also appeared in the course of a lively debate and they have had an impact on British-Turkish relations. In may 2016, British weekly "The Spectator", which has been published since 1711, organised a contest for its readers. The rules were simple - one had to make a poem referring to the Turkish president's controversial statement. Boris Johnson presented a four-verse poem in an interview for a Swiss newspaper. It depicted "love that flourished between the Turkish president and a goat." It made the Turkish people outraged, especially as the mayor of London was granted a prize of one thousand pounds for winning the contest (Poezja wulgarna..., 2016). The situation was even more awkward as Boris Johnson's great grandfather, Ali Kemal, was Turkish (liberal politician and journalist). During his visit to Turkey, Boris Johnson emphasised the importance of economic relations between the United Kingdom and Turkey. According to Ndie.pl, the British minister of foreign affairs did his best to improve his reputation after he had implied in his poem that President Erdogan had made love to a goat (Boris Johnson: Wielka..., 2016).

As it was mentioned before, the United Kingdom has been a long time ally of Turkey and supported its attempts to obtain European Union membership. On 28 January 2017, President Recep Tayyip Erdogan met British Prime Minister Theresa May in his presidential palace. The fact that she had planned to visit Turkey just after meeting President Donald Trump in Washington, where she discussed some key trade agreements that were to strengthen her position in negotiations with the European Union about Brexit, is a proof how important for London good relations with Ankara are (Brytyjska premier: Turcja..., 2017). During her visit to Turkey, Theresa May admitted that as a result of Great Britain's decision to leave the EU Turks had lost the biggest advocate of their interests in Europe. The comments of Turkish politicians have been quite moderate so far. May declared that both countries agreed to establish a joint work group to stimulate trade relations in the period after the UK's leaving the EU. Erdogan declared that trade exchange between Turkey and Britain would reach the level of 20 billion dollars (compared to 15.6 billion at present) (May zaapelowata..., 2017). What is more, the prime ministers of both countries addressed the issue of the war against terrorism (Jihadists), 
the situation in Cyprus, trade, immigration crisis and questions concerning the Middle East. Turkey and the United Kingdom signed a 100 million pound contract concerning the cooperation in the development of Turkish air fighters (Туриия разработает..., 2017). President Recep Tayyip Erdoğan said that the UK's decision to leave the Community was a surprise for him. He blamed the European elites and their policy for what had happened. According to Erdogan, if "the EU does not fight its contradictions, there will be more departures" (Brexit szansq..., 2016).

It should be noted that the Turkish president, on 25 March 2017, at the British-Turkish political-cultural-economic forum in Antalya in the south of the country, proposed a nationwide referendum, modelled after the British one (referred to as Turkish "Brexit" vote in Turkish media) (Web-videos, n.d.), in which citizens would be asked to express their opinion on the issue of the continuation of accession talks with the European Union (Turkey's Erdogan wants..., 2017).

\section{$* * *$}

To conclude, it is obvious that Turkey's foreign policy priorities (see Misiagiewicz, 2009; Gwiazda, 2005, pp. 3-10; Konopacki, 2005, pp. 49-62), including the decision whether to continue the negotiation process with the EU, will be largely influenced by the EU's redefined policy after the UK leaves the Community. What additionally makes the situation worse is the recent tightening of relations with Germany and the Netherlands, which have refused to allow Turkish politicians to enter their territory as a protest against the constitutional referendum (held on 16 April 2017) on changing the political system of Turkey from the parliamentary-cabinet one to the presidential regime (Turkey's Erdogan wants..., 2017). At present, EU-Turkey relations are not quite friendly. There are a variety of reasons for such a state of affairs and Turkey is responsible for many of them, but there is no doubt that European politicians are not faultless, either. They often pass judgements concerning Ankara quite severely and brusquely, which leads to the cooling of mutual relations. As Sir Alan Duncan accurately remarks, "there has been insufficient understanding in many quarters, particularly within the membership of the European Union, about what Turkey had to face and still faces [...] What was important with the Turks was to ask the questions and understand first, before criticising later. The EU was overcritical too quickly [...]. Our judgment in making it absolutely clear that we [the UK] understand what they [Turkey] have been going through has been the right one. I am pleased to say that they appreciate it and we appreciate their appreciation" (House of Commons Foreign..., 2017).

Turkey is undergoing another crisis. It is a state with a huge potential and for Great Britain it is one of the most dynamic partners among developing markets. After Brexit, the UK government needs to make every effort to strengthen its position at the international arena. Theresa May's visit to Turkey appeared to be the first step on the way of seeking a new format of the policy of cooperation with the main partners in Europe and focusing on bilateral ties. The British prime minister's talks in Ankara, just after her visit to the US, should thus be seen as the beginning of building a new strategy. The model of Turkish-British ties may become an example for relations within the Community. 
In the face of the approaching $100^{\text {th }}$ anniversary of the establishment of the Republic of Turkey various aspects of Turkish policy are becoming subject to change. Turkey is putting increasing emphasis on Eastern security policy, thinking of the Shanghai Cooperation Organisation as an alternative to membership in the European Union (see Burak, 2015, pp. 56-65). For Turkey, Brexit was a signal that revealed the weakness of EU structures and made politicians reflect on the direction of changes. The future will show whether Turkish politicians are right predicting that Brexit is the first stage on the way to the inevitable disintegration of the European Union. A lot depends on politicians and their ability to work out compromises, willingness to conduct dialogue and to cooperation, professionalism. UE-Turkey relations can still be improved. What is needed are good will and understanding for particularist interests. There is no doubt that mutual trust may serve as the foundation for building future partner relations. A question arises whether in such turbulent times the Union can afford to lose Turkey as its member and let it seek cooperation with Eastern partners instead, which will also involve a risk of having to admit immigrants from Syria. If an agreement is not reached, the Turkish prediction may come true. The European Union, thus also the European security system, may not bear a double shock: Brexit and the further worsening of relations with Turkey - a country located in the strategic region of the Middle East.

\section{Bibliography}

Alkan M. N. (2013), Türkiye'deki Üniversite Öğrencilerinin Avrupa Birliği Algısl, Konrad-AdenauerStiftung e.V., Ankara.

Altun M. (2016, June 23), Avrupa Birliği'ne referandum resti. Sabah Gazetesi, http://www.sabah.com. tr/gundem/2016/06/23/avrupa-birligine-referandum-resti, 4 April 2017.

Ambroziak A. A. (1996), Nowe wyzwania dla Turcji i UE w ramach unii celnej (I), "Wspólnoty Europejskie - Biuletyn Informacyjny", no. 1, p. 13.

Białek M. (2017, March 25), Relacje Turcja - Wielka Brytania w kontekście BREXITu, the opinion of D. Kawczyński, member of the British House of Commons, http://www.wiadomosci24.pl/ artykul/relacje_turcja_wielka_brytania_w_kontekscie_brexitu_360241.html, 2 April 2017.

Birleşik Krallık Dışişleri Bakanı Boris Johnson 25-27 Eylül 2016 tarihleri arasında Türkiye'yi ziyaret etti (2016, September 29), "Birleşik Krallık Ankara Büyükelçiliği”, https://www.gov.uk/government/world-location-news/uk-foreign-secretary-boris-johnsons-visit-to-turkey.tr, 22 March 2017.

Boris Johnson: Wielka Brytania pomoże Turcji przystapić do UE (2016, September 27), "ndie.pl", https://ndie.pl/boris-johnson-wielka-brytania-pomoze-turcji-przystapic-ue/, 30 March 2017.

Boris Johnson zrobit Brexit teraz chce Turkentry (2016, September 28), “Euro Islam”, https://euroislam. pl/boris-johnson-zrobil-brexit-teraz-chce-turkentry/, 22 March 2017.

Brexit: czy w Europie jest jeszcze miejsce dla Turcji? (2016, June 28), “Onet.pl”, http://wiadomosci. onet.pl/swiat/brexit-czy-w-europie-jest-jeszcze-miejsce-dla-turcji/tj91be, 6 April 2017.

Brexit szansq dla Turcji na członkostwo w UE? (2016, June 29), Radiowa Jedynka, "Wprost.pl”, https://www.wprost.pl/swiat/10013066/Brexit-szansa-dla-Turcji-na-czlonkostwo-w-UE.html, 30 March 2017.

Brytyjczycy wybrali Brexit (n.d.), "tvn24”, http://www.tvn24.pl/raporty/brytyjczycy-wybrali-brexit,606, 4 April 2017. 
Brytyjska premier: Turcja musi przestrzegać praw człowieka i zasad praworzadności (2017, January 28), "Polskie Radio", http://www.polskieradio.pl/5/3/Artykul/1721231,Brytyjska-premierTurcja-musi-przestrzegac-praw-czlowieka-i-zasad-praworzadnosci, 30 March 2017.

Burak A. (2015), Euroazjatycka Wspólnota Gospodarcza i Szanghajska Organizacja Wspótpracy jako alternatywa dla Turcji wobec braku członkostwa w Unii Europejskiej, "Nowa Polityka Wschodnia", no. 2 (9), pp. 56-65.

Burak A. (2016), Wpływ kryzysu syryjskiego na emigracje uchodźców do Turcji, in: A. Burak, N. Gburzyńska, Turcja w XXI wieku, Adam Marszałek, Toruń, pp. 52-78.

Cameron: Türkiye AB'ye 3000 yllında üye olur (2016, June 20), “AHaber”, http://www.ahaber.com.tr/ dunya/2016/06/20/cameron-turkiye-abye-3000-yilinda-uye-olur, 5 April 2017.

CHP'den Brexit değerlendirmesi (2016, June 29), “AB Haber”, http://www.abhaber.com/chpden-brexit-degerlendirmesi/, 6 April 2017.

Dalay G. (2016, June 12), Brexit may be a good thing for Turkey, Al Jazeera, http://www.aljazeera.com/ indepth/opinion/2016/07/brexit-good-turkey-160711124421322.html, 5 April 2017.

European Council of the European Union, U-Turkey statement (2016, March 18), http://www.consilium.europa.eu/en/press/press-releases/2016/03/18-eu-turkey-statement/, 2 April 2017.

Gwiazda A. (2005), Członkostwo Turcji w Unii Europejskiej - szanse i zagrożenia, "Wspólnoty Europejskie", no. 10 (167), pp. 3-10.

House of Commons Foreign Affairs Committee (2017, March 25), The UK's relations with Turkey. Tenth Report of Session 2016-17, Ordered by the House of Commons to be printed 21 March 2017, HC 615, https://www.publications.parliament.uk/pa/cm201617/cmselect/cmfaff/615/615.pdf, 7 April 2017.

Jarosiewicz A. (2017 February 1), Turcja i Wielka Brytania: wspótpraca bez Brukseli, “OSW”, https:// www.osw.waw.pl/pl/publikacje/analizy/2017-02-01/turcja-i-wielka-brytania-wspolpraca-bezbrukseli, 4 April 2017.

Jurkowska B. (2010, August 26), Proces integracji Turcji z Uniq Europejska, http://stosunki-miedzynarodowe.pl/unia-europejska/1078-proces-integracji-turcji-z-unia-europejska, 5 April 2017.

Kaleağası B. (2010), Nolcak Bu AB İşi?, Boyut Yayın Grubu, Istanbul.

Kasapoğlu Ç. (2016, June 17), İngiltere'nin AB referandumu ve Türkiye tartışmaları, "BBC Türkçe", http://www.bbc.com/turkce/haberler/2016/06/160616_ab_referandum_turkiye, 5 April 2017.

Konopacki S. (2005), Droga Turcji do Unii Europejskiej, "Studia Europejskie”, no. 1, pp. 49-62.

Köylü H. (2016, June 24), Brexit Türkiye'yi nasıl etkileyecek?, "DW", http://www.dw.com/tr/brexitt\%C3\%BCrkiyeyi-nas\%C4\%B11-etkileyecek/a-19355865, 2 April 2017.

May zaapelowata do Turcji o przestrzeganie praw czlowieka (2017, January 28), "rp.pl”, http:// www.rp.pl/Swiat/170128928-May-zaapelowala-do-Turcji-o-przestrzeganie-praw-czlowieka. html\#ap-1, 29 March 2017.

Mehmet Şimşek ve Nurettin Canikli'den Brexit tweeti (2016, June 24), "Karar Gazetesi”, http://www. karar.com/ekonomi-haberleri/hukumetten-ilginc-mesaj-168686, 2 April 2017.

Mevlüt Çavuşoğlu'ndan Brexit ardından ilk açılama (2016, June 24), "Haber Türk", http://www. haberturk.com/dunya/haber/1258436-mevlut-cavusoglundan-brexit-ardindan-ilk-aciklama, 21.03.2017.

Mikail E. H., Künü S., Durmuş S., Karabulut A. (2015), Türkiye’nin Kafkasya ve Orta Asya Ülkeleri İle Siyasi-İktisadi-Kültürel İlişkileri, Derin Yayınları, Istanbul.

Misiagiewicz J. (2009), Polityka zagraniczna Turcji po zimnej wojnie, Adam Marszałek, Toruń.

Örmeci O. (2016), Son Yillarda Türkiye-Birleşik Krallık (İngiltere) İlişkileri: İlişkilerde "Altın Çăg Dönemi Mi??, "Süleyman Demirel Üniversitesi İktisadi ve İdari Bilimler Fakültesi Dergisi”, vol. 21, no. 2, p. 603. 
Poezja wulgarna - Boris Johnson z nagroda za... wiersz o seksie z kozq (2016, May 19), "Express Polish", http://www.polishexpress.co.uk/poezja-wulgarna-boris-johnson-z-nagroda-za-wierszo-seksie-z-koza, 30 March 2017.

Rozpoczyna się Brexit, czyli wyjście Wielkiej Brytanii z UE. Co to oznacza w praktyce (2017, March 29), "Newsweek Polska", http://www.newsweek.pl/swiat/polityka/brexit-czyli-wyjscie-wielkiej-brytanii-z-ue-co-to-oznacza-,artykuly,407297,1.html, 1 April 2017.

Şimşek Y. (2016, June 24), MHP'den AB yorumu: Uzun nişanlılığ töremiz kaldırmaz. evleneceksek evlenelim, "Sputnik", https:/tr.sputniknews.com/politika/201606241023548979-mhp-ab-evlilik/, 6 April 2017.

The Electoral Commission (n.d.), EU referendum results, http://www.electoralcommission.org.uk/findinformation-by-subject/elections-and-referendums/past-elections-and-referendums/eu-referendum/electorate-and-count-information, 4.042017.

Theresa May signs $£ 100$ m fighter jet deal with Turkey’s Erdoğan (2017, January 28), https://www. theguardian.com/politics/2017/jan/28/theresa-may-signs-100m-fighter-jet-deal-with-turkeyserdogan, 6 April 2017.

Turkey's Erdogan wants Brexit-like vote on pursuit of EU membership (2017, April 4), "Deutsche Welle", http://www.dw.com/en/turkeys-erdogan-wants-brexit-like-vote-on-pursuit-of-eumembership/a-38122493, 6 April 2017.

Vote Leave embroiled in race row over Turkey security threat claims (2016, May 21), "The Guardian", https://www.theguardian.com/politics/2016/may/21/vote-leave-prejudice-turkey-eu-securitythreat, 25 March 2017.

Web-videos (n.d.), Erdogan proposes Turkish 'Brexit' vote, http://www.dw.com/en/turkeys-erdoganwants-brexit-like-vote-on-pursuit-of-eu-membership/a-38122493, 6 April 2017.

Wielka Brytania rozpoczyna Brexit. Tusk: W tym procesie nie ma nic do wygrania i mówię tu o obu stronach. W istocie chodzi o ograniczenie szkód (2017, March 29), "Newsweek Polska", http:// www.newsweek.pl/swiat/polityka/donald-tusk-o-brexicie-wielka-brytania-wychodzi-z-unii,artykuly,407886,1.html, 5 April 2017.

США: ЕС отвечает за изменение внешней политики Туриии (2010, June 9), “ЛІГАБізнесІнформ”, http://news.liga.net/news/world/483907-ssha-es-otvechaet-za-izmenenie-vneshney-politikiturtsii.htm, 4 April 2017.

Туриия готова реализовать широкомасштабный торговый договор с Великобританией после «брексит» (2016, November 11), “РИА Новости", http://novostink.ru/mir/180470-turciyagotova-realizovat-shirokomasshtabnyy-torgovyy-dogovor-s-velikobritaniey-posle-breksit. html\#ixzz4d2DPefey, 1 April 2017.

Туриия разработает с Британией новый истребитель (2017, January 28), “Корреспондент”, http://korrespondent.net/world/3807312-turtsyia-razrabotaet-s-brytanyei-novyi-ystrebytel, 30 March 2017.

\section{Krajobraz po Brexicie obserwowany z perspektywy Ankary. Czy "rozwodowa" decyzja Wielkiej Brytanii dodatkowo rozluźni więzi UE-Turcja i wpłynie na przyszłość Europy?}

\section{Streszczenie}

29 marca 2017 r. szef Rady Europejskiej Donald Tusk otrzymał od brytyjskiego ambasadora Tima Barrowa pismo, które uruchamia zapisaną w artykule 50 traktatu lizbońskiego procedurę wystapienia Wielkiej Brytanii z Unii Europejskiej. Gideon Rachman z "Financial Times" porównał Brexit z rozwodem, stwierdzając, że przedstawiciel rządu brytyjskiego w Brukseli "wręczył papiery rozwodowe" i tym samym zapoczątkował "długotrwałą (na razie zaplanowaną na ponad dwa lata) próbę poukładania 
sobie stosunków na nowo". Z kolei w oświadczeniu dla prasy D. Tusk skomentował to wydarzenie w następujący sposób: "Nie ma powodu, żeby udawać, że to szczęśliwy dzień, zarówno w Brukseli, jak i Londynie [...] Większość Europejczyków, włączając w to prawie połowę brytyjskich głosujących, wolałaby, żebyśmy zostali razem". Z całą pewnością stanowisko RE odzwierciedla nastroje wywołane przez decyzję o Brexicie, które są i będą odczuwalne dla wszystkich państw członkowskich Wspólnoty. Warto jednak zauważyć, że opuszczenie przez Brytyjczyków UE oddziałuje nie tylko na sytuację polityczną ich samych, ale także określa działania władz państw aspirujących do członkostwa we Wspólnocie. Celem niniejszego artykułu nie jest omówienie powodów Brexitu, ale zaprezentowanie postawy tureckiego rządu. W tym kontekście na podstawie analizy artykułów prasowych oraz wystąpień polityków omówiona zostanie prawdopodobna strategia Ankary. Teza, którą postawiliśmy, zakłada, że wraz z Brexitem Turcja straciła jedyne poparcie na drodze wejścia do Unii Europejskiej. Turcja zaczyna nowy etap w stosunkach między UE i Wielką Brytanią. Należy się również zastanowić, jak Turcja postrzega i ocenia prowadzoną obecnie politykę zewnętrzną, zredefiniowaną przez trwający konflikt w Syrii, walkę z ISIS i problem imigracyjny, oraz bezcelowość procesu prowadzącego do opuszczenia Unii Europejskiej przez Wielką Brytanię. Jaki będzie kierunek tureckiej polityki zagranicznej w relacjach z Zachodem? Czy Turcja odejdzie od statusu kandydata unijnego (tzw. Turexit)?

Słowa kluczowe: Brexit, Wielka Brytania, Turcja, Unia Europejska 